\title{
Short Communication: \\ A comparison of stand structure, species diversity and aboveground biomass between natural and planted mangroves in Sikka, East Nusa Tenggara, Indonesia
}

\author{
JERIELS MATATULA ${ }^{1}$, AHMAD YUSUF AFANDI ${ }^{2}$, PANDU YUDHA ADI PUTRA WIRABUANA ${ }^{3, \bullet}$ \\ ${ }^{1}$ Forestry Field Program, Politeknik Pertanian Negeri Kupang. Jl. Prof. Herman Johanes, Lasiana, Kupang 85011, East Nusa Tenggara, Indonesia \\ ${ }^{2}$ Research Center for Limnology, Indonesia Institute of Sciences. Jl. Raya Bogor-Jakarta Km. 46, Cibinong, Bogor 16911, West Java, Indonesia \\ ${ }^{3}$ Department of Forest Management, Faculty of Forestry, Universitas Gadjah Mada. Jl. Agro No. 1, Bulaksumur, Sleman 55281, Yogyakarta, Indonesia. \\ Tel./fax.: +62-274-548815, •email: pandu.yudha.a.p@ugm.ac.id
}

Manuscript received: 19 January 2021. Revision accepted: 30 January 2021.

\begin{abstract}
Matatula J, Afandi AY, Wirabuana PYAP. 2021. Short Communication: A comparison of stand structure, species diversity and aboveground biomass between natural and planted mangroves in Sikka, East Nusa Tenggara, Indonesia. Biodiversitas 22: $1098-1103$. The effectiveness of mangroves reforestation can be evaluated by comparing the stand dynamics of planted mangroves with natural mangroves in similar site conditions. This study investigated stand structure, species diversity and aboveground biomass between natural and planted mangroves in Sikka, East Nusa Tenggara, Indonesia. A field survey was conducted using quadrat transect method for vegetation measurement, especially related to species composition and its size distribution. Several parameters were recorded in field observation, including number of species, diameter, height, volume, and aboveground biomass. The stand structure of both mangroves was demonstrated by the distribution of diameter class while the species diversity was described using three parameters, i.e., richness, heterogeneity, and evenness. Moreover, the IVI of each species recorded was also calculated to understand the contribution of species in the mangrove ecosystems. The comparison of stand characteristics between natural and planted mangroves was examined by Mann-Whitney test and Spearman Correlation was also applied to understand the relationship between IVI and aboveground biomass. The results showed that the diameter and height between the natural and planted mangroves significantly differed $(P<0.05)$. In contrast, there was no significant difference in tree density, volume, and aboveground biomass $(P<0.05)$. The stand structure of both mangrove stands followed the pattern of J-inverse in which the frequency of trees decreased with the increase in diameter class. Species diversity in both stands was statistically equal in richness, heterogeneity, and evenness $(P>0.05)$ even though there were some specific species which only observed in the natural or planted mangroves. The most superior species in the planted mangroves was Rhizophora mucronata $(\mathrm{IVI}=96.99)$ while the most important plant in the natural mangroves was Sonneratia alba (IVI = 82.49). Our study found there was a significant correlation between IVI and aboveground biomass in which species with higher IVI indicated greater aboveground biomass. Based on these findings, restoration efforts of degraded mangroves in Sikka have been effective. The restoration, which has been conducted for almost three decades, has not only brought back its vegetation cover but also the functional traits of the mangrove stand to mimic with natural mangroves in the area.
\end{abstract}

Keywords: Mangroves, heterogeneity, richness, reforestation, stand dynamics

\section{INTRODUCTION}

Sustainable management of mangroves currently becomes an essential issue globally since this is the key to maintain the stability of coastal areas. Besides becoming a habitat for a large number of biotas (Sihombing et al. 2017), mangroves play an important role in preventing abrasion and inhibiting sea-water intrusion (Sadono et al. 2020a). This ecosystem also has a significant contribution to climate change mitigation by storing rich amount of carbon in the form of biomass of its vegetation as well as in the soils (Taillardat et al. 2018). Some literature reported carbon stock in mangroves ranges from 3.4 to $218.2 \mathrm{Mg}$ ha ${ }^{-1}$ depending on age of stand and site characteristics (Luo et al. 2010). In the context of economic development, mangroves also provide a positive advantage to improve the prosperity of communities living in coastal areas (Kusmana and Sukristijiono, 2016). Mangrove forest is a source of non-timber forest products with high economic value, particularly related to fisheries and tannins (Debrot et al. 2020).

Indonesia is one of the tropical countries which has a large extent of mangroves. A study stated that there are more than 4.5 million hectares of mangrove ecosystems in the country (Susilo et al. 2017). It is equivalent to $23 \%$ of the total mangrove forests in the world, making Indonesia the nation with largest extent of mangrove areas globally (Richards and Friess, 2016). However, the mangroves cover in Indonesia has declined rapidly due to the impact of human activities, such as timber extraction, the development of infrastructures and human settlements, land conversion for fish and shrimp ponds, sand-mining and environmental pollution (Sadono et al. 2020b). Not only triggering mangrove deforestation, but such activities also cause mangrove degradation which reduces the function of mangrove ecosystems in delivering environmental services 
in the coastal area. Several studies also provide evidence that the deforestation and degradation of mangroves have strong relationships with the occurrence of natural disturbances in coastal areas, primarily those related to wind-damage and sea-water flooding (Marois and Mitsch, 2015; Koh et al. 2018; Dasgupta et al. 2019). Therefore, to maintain the existence of mangroves and to minimize the negative impacts of mangrove deforestation and degradation, reforestation efforts have been extensively conducted in many countries, including in Indonesia. However, the implementation of mangrove re-vegetation is not easy since it requires active participation of community as the main actor to ensure the success of reforestation program. In addition, the primary challenge of mangrove rehabilitation is not only about re-planting to increase the mangrove cover, but also to recover the ecosystem functions of mangrove ecosystems. This condition leads a question of whether the activity of reforestation in mangroves is effective to maintain its existence and to revive its ecological attributes.

Therefore, it is important to understand the differences in stand characteristics between the planted mangroves and those that grow naturally. If both mangroves have similar stand attributes, it indicates that the activity of reforestation is effective to support the recovery of mangrove forests. For that reason, this study aimed to compare the stand structure, species diversity, and aboveground biomass between natural mangrove stands and planted mangroves after long-term reforestation program. The study area was focused on the mangrove forest in Sikka, East Nusa Tenggara Province, Indonesia. Our study provides a unique context of study as not many studies in the theme of mangroves have been conducted in Sikka, and more broadly in the eastern region of Indonesia, let alone on the specific issue of mangrove restoration. As such, we believe that this study is the first to fill such knowledge gap and adds a new understanding of mangrove restoration in eastern part of Indonesia.

\section{MATERIALS AND METHODS}

\section{Study area}

This study was conducted in mangrove ecosystems in the coast of Sikka, East Nusa Tenggara, Indonesia. This area has geographic coordinates of $8^{\circ} 22^{\prime}-8^{\circ} 50^{\prime} \mathrm{S}$ and $121^{\circ} 55^{\prime}-122^{\circ} 41^{\prime} \mathrm{E}$ (Figure 1). The study site had two different types of mangrove stand, namely natural and planted mangroves. The area of natural mangroves was a remnant mangrove that survived the tsunami disaster in 1992. The planted mangroves were developed from a longterm reforestation program since 1993. The biophysical conditions of both mangroves were relatively similar since the area of natural mangroves was located alongside the planted mangroves. The study site had dry climate with the annual rainfall ranging from 1,000 to $1,500 \mathrm{~mm}_{\text {year }}{ }^{-1}$ and air humidity varied from 64 to $86 \%$. The mean daily temperature reached $31^{\circ} \mathrm{C}$ with a minimum of $20^{\circ} \mathrm{C}$ and a maximum of $33^{\circ} \mathrm{C}$. The dry season was generally longer than 7 months, starting from April to November.

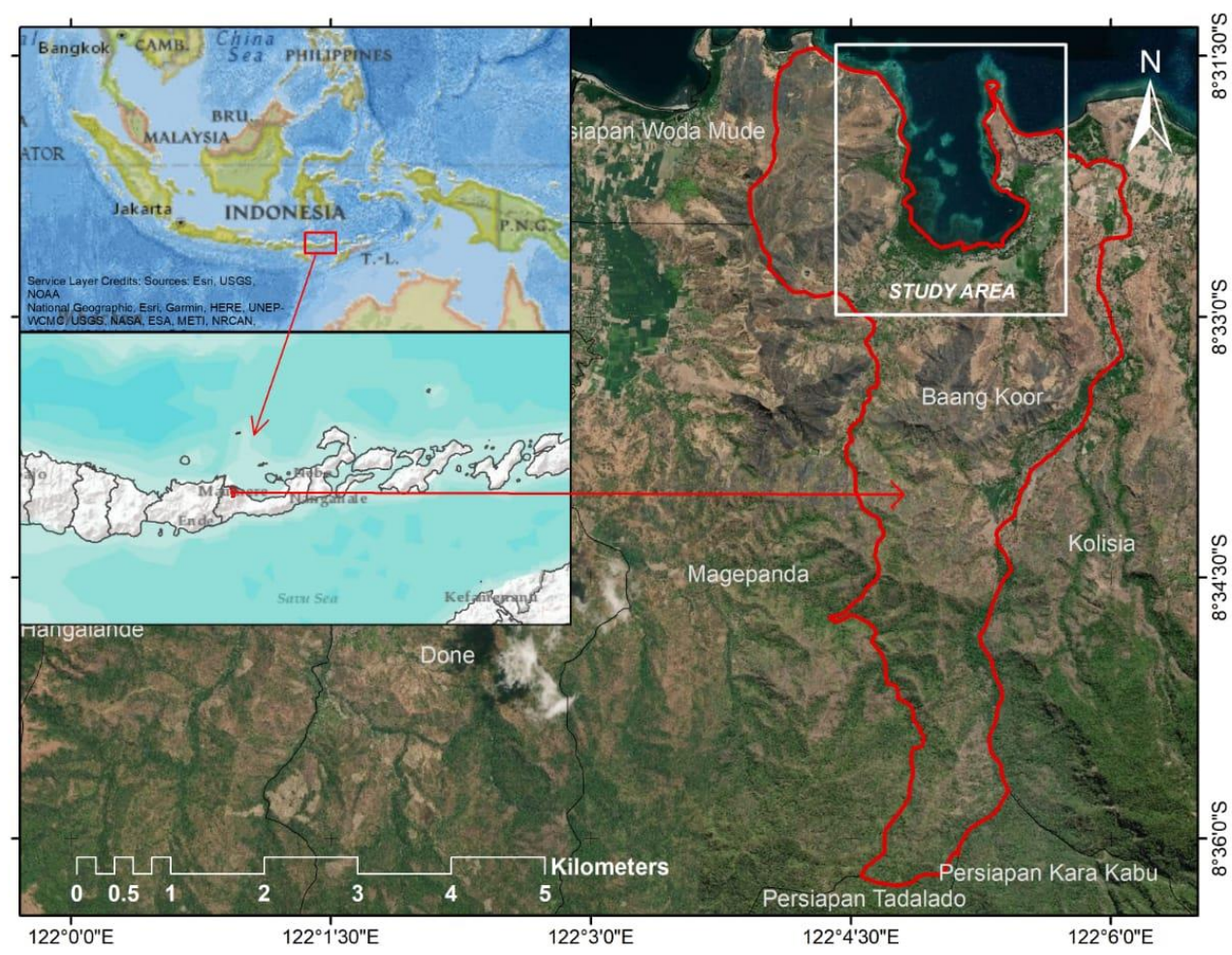

Figure 1. The study area of mangrove ecosystems at the coast of Sikka, East Nusa Tenggara, Indonesia. The white polygon indicated the area of mangrove forest for observation location 


\section{Data collection}

Data collection was conducted from October to November 2020. A field survey was designed to measure the vegetation condition in natural and planted mangroves using a quadrat transect method. There were six transects established which were evenly distributed in both types of mangrove stands with the size of quadrat plot in each transect was $10 \mathrm{~m} \times 10 \mathrm{~m}$ and the distance of each quadrat was $50 \mathrm{~m}$ x $50 \mathrm{~m}$ (Figure 2). It was placed systematically to represent the environmental variation of mangrove forests. Several parameters were recorded from the observation plot, including type of species, diameter, and, height. During the field measurement, there were no seedlings and saplings in all of the transects both in natural or planted mangroves.

\section{Data analysis}

The data were analyzed to obtain the number of species density (individual ha $\left.{ }^{-1}\right)$, basal area $\left(\mathrm{m}^{2}\right.$ ha $\left.{ }^{-1}\right)$, and frequency (\%) (Eddy et al. 2019). Then, those parameters were transformed into relative abundance, relative dominance, and relative frequency (Kasim et al. 2019). The importance value index (IVI) for every species in mangroves was determined based on the accumulation of those three indicators. In the context of ecological studies, the availability of information about IVI is essentially necessary to understand the fundamental position of species present in ecosystems (Yuliana et al. 2019). The diversity of species between the natural and planted mangroves was also assessed using three parameters, namely richness (Margalef Index), heterogeneity (ShannonWiener Index), and evenness (Pielou Index) (Singh, 2020).

To evaluate the regeneration capacity of the natural and planted mangroves, an analysis of stand structure was undertaken using the pattern of diameter distribution. This approach is generally used to describe the stand structure of even-aged and uneven-aged forests (Sghaier et al. 2016). In forest ecosystems, tree diameter is a growth attribute which commonly used to categorize the life form of woody species (Pamoengkas et al. 2018). The size of tree diameter commonly increases following the age of tree. A good regeneration capacity of forests can be reviewed from the balance distribution of tree density in each diameter class (Gebeyehu et al. 2019). Principally, it would be better if the population of young trees is relatively higher than that of older trees to ensure the continuity of regeneration process.

The growth performance of stand between the natural and planted mangroves was also analyzed using several parameters, including mean diameter, average height, wood volume, and aboveground biomass. Individual tree volume and aboveground biomass of each species were calculated as follows:

$$
\begin{aligned}
& \mathrm{V}=0.25 \pi \times \mathrm{D}^{2} \times \mathrm{H} \\
& A G B=V \times W D \times B E F
\end{aligned}
$$

Where; $V$ is tree volume, $D$ is diameter at breast height, $H$ is tree height, $A G B$ is aboveground biomass, $W D$ is wood density, and $B E F$ is biomass expansion factor. The details of $W D$ and $B E F$ of each mangrove species are presented in Table 1.

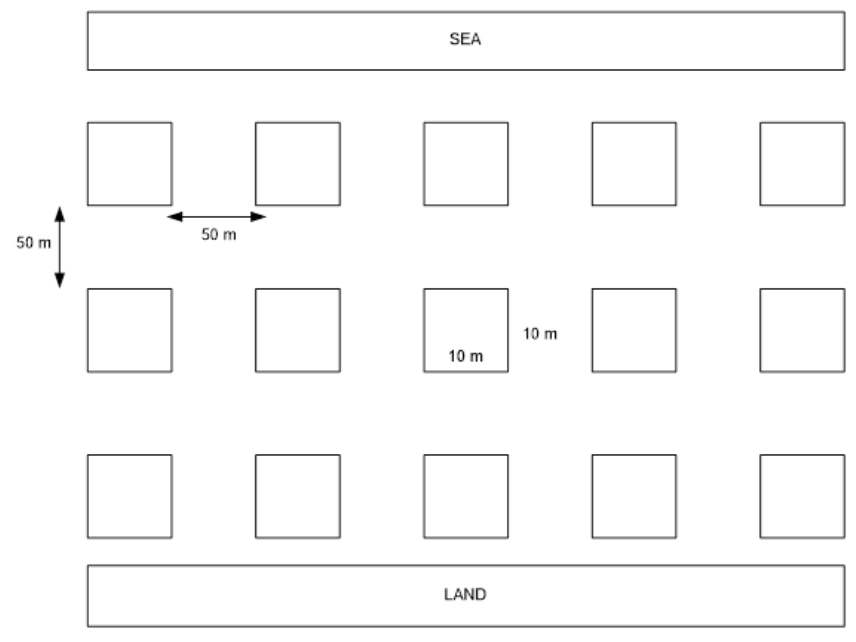

Figure 2. The design of field survey using quadrat transect method to measure observed variables in the natural and planted mangroves at the coast of Sikka, East Nusa Tenggara, Indonesia. The transect was made from the land toward the sea to cover mangroves zonation

Table 1. Wood density and biomass expansion factor of each

\begin{tabular}{|c|c|c|c|}
\hline Species & $\begin{array}{c}\text { WD } \\
\left(\mathrm{kg} \mathrm{m}^{-3}\right)\end{array}$ & BEF & Reference \\
\hline Avicennia marina & 731.6 & 1.74 & Dinilhuda et al. (2020) \\
\hline Ceriops tagal & 885.9 & 1.53 & Hossain et al. (2016) \\
\hline Rhizophora mисronata & 848.3 & 1.34 & Krisnawati et al. (2012) \\
\hline Aegiceras corniculatum & 596.7 & 1.57 & Komiyama et al. (2000) \\
\hline Avicennia alba & 698.7 & 1.25 & Njana (2017) \\
\hline Bruguiera gymnorrhiza & 784.2 & 1.61 & Krisnawati et al. (2012) \\
\hline Lumnitzera racemosa & 832.5 & 1.41 & Kangkuso et al. (2016) \\
\hline Rhizophora apiculata & 881.4 & 1.55 & Krisnawati et al. (2012) \\
\hline Sonneratia alba & 644.3 & 1.62 & Njana (2017) \\
\hline
\end{tabular}
mangrove species

Note: the data of wood density were obtained from ICRAF database while the information about biomass expansion factor was derived from literature study.

Statistical analyses were conducted using $\mathrm{R}$ software 4.2.1 with a significant level of 5\%. The normality of data was evaluated using Shapiro-Wilk test. The comparison of stand characteristics between the natural and planted mangroves was examined using Mann-Whitney test. Analysis of Spearman Correlation was also applied to assess the relationship between IVI and aboveground biomass of mangrove species.

\section{RESULTS AND DISCUSSION}

The results of the observation showed that tree density in varying diameter classes between the natural and planted mangroves in Sikka is relatively similar which follows the pattern of J-inverse (Figure 3). The highest tree density was recorded in small diameter class while the lowest was found in big diameter class. Despite having a similar pattern, the tree density in small and medium diameter class from the planted mangroves was slightly higher than that in the natural mangroves. In contrast, a different trend 
was noted in big diameter class in which the tree density of the natural mangroves was substantially higher than that in the planted mangroves. The similarity in stand structure between the natural and planted mangroves in Sikka was likely due to the implementation of reforestation in planted mangroves that was conducted gradually from 1993 to 2008. Therefore, the stand condition in planted mangroves also had high variation in age and growth.

Several literature explains that forest with uneven ages tends to have the pattern of J-inverse in stand structure due to the multispecies nature and high variation in growth (Bauhus et al. 2002; Westphal et al. 2006; Pukkala et al. 2010). This pattern also indicates that the forest ecosystems in both stands had good regeneration capacity since there were adequate young trees to support stand regeneration (Sinha et al. 2017). This condition also directly suggest that both mangrove forest stands had a complex vertical structure with dense crown layer (Angelini et al. 2015). Based on these findings, it was clearly confirmed that the planted mangroves in Sikka had sufficient regeneration capacity similar to the natural mangroves.

While there was a similar pattern in stand structure between the natural and planted mangrove stands, this study observed the species composition between both stands was comparatively different. In this case, the number of species in the natural mangroves was slightly higher than that in the planted mangroves (Table 2). In the planted mangroves, there were only six species found, i.e., Avicennia marina, Ceriops tagal, Lumnitzera racemosa, Rhizophora apiculata, Rhizophora mucronata and Sonneratia alba. On the other hand, the natural mangroves consisted of seven plant species, namely A. marina, $C$. tagal, $R$. mucronata, S. alba, Aegiceras corniculatum, A. alba, and B. gymnorrhiza. Based on these results, it seems that there were several specific species which only observed in certain mangrove ecosystems. Aegiceras corniculatum, A. alba, and $B$. gymnorrhiza were only found in natural mangroves while $L$. racemosa and $R$. apiculata were only recorded in planted mangroves. This circumstance has occurred because of the availability of planting materials when conducting reforestation program which still depended on plants that produce large number of seeds, such as A. marina, C. tagal, R. mucronata and S. alba.

Our study recorded the most important species between in the natural mangrove stand and the planted mangrove was also different (Table 2). In the planted mangroves, $S$. alba was the most superior with IVI 82.49, while $R$. mucronata was the most important species in the natural mangroves with IVI of 96.99. Many studies reported that species with higher IVI play more important contribution in forest ecosystems, particularly related to forest productivity (Guèze et al. 2014; Turkis and Elmas, 2018; Yuliana et al. 2019). It was also supported by our findings wherein there was a significant correlation between IVI and aboveground biomass of each species (Figure 4). The higher IVI demonstrated a greater biomass accumulation from species in mangrove ecosystems. This fact was also strengthened by our results in which the accumulation of aboveground biomass from $R$. mucronata was the greatest in the natural mangroves and $S$. alba was the highest in the planted mangroves (Figure 5).

Despite having different species composition, our study found the species diversity of both mangrove stands was statistically similar in richness, evenness and heterogeneity (Table 3). A similar trend was also shown in tree density, wood volume, and aboveground biomass. However, the mean diameter and average height between the natural and planted mangroves differed significantly $(P<0.05)$. This difference was likely caused by the different growth performance of species in each forest in which based on four similar species that lived in both mangroves, the majority of plants in the natural mangroves demonstrated better growth than trees in the planted mangroves, except for $S$. alba (Figure 6). This fact explained why the wood volume and aboveground biomass in both mangrove stands were statistically similar even though the number of tree densities in natural mangroves was lower than that in the planted mangroves.

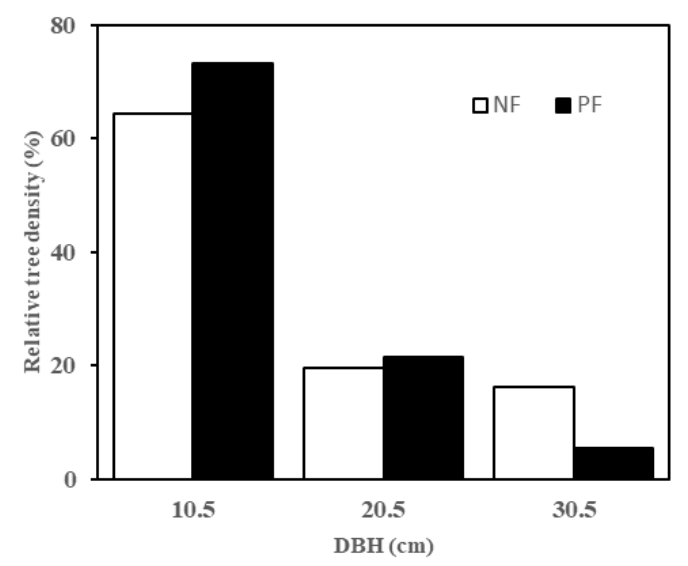

Figure 3. Comparison stand structure between the natural mangroves (NF) and the planted mangroves (PF) in the coast of Sikka, East Nusa Tenggara, Indonesia. The number of tree densities in each diameter class was showed in relative frequency.

Table 2. Relative abundance (RA), relative dominance (RD), relative frequency (RF), and important value index (IVI) of each mangrove species in the natural and planted mangroves stands

\begin{tabular}{lrrrrc}
\hline Species & \multicolumn{1}{c}{ RA } & \multicolumn{1}{c}{ RD } & \multicolumn{1}{c}{ RF } & IVI & Rank \\
\hline Natural mangrove forest & & & & & \\
Avicennia marina & 20.00 & 16.20 & 26.32 & 62.52 & II \\
Ceriops tagal & 6.67 & 0.79 & 5.26 & 12.72 & VI \\
Rhizophora mucronata & 30.00 & 40.68 & 26.32 & 96.99 & I \\
Sonneratia alba & 16.67 & 23.13 & 21.05 & 60.85 & III \\
Aegiceras corniculatum & 20.00 & 18.08 & 5.26 & 43.34 & IV \\
Avicennia alba & 3.33 & 0.90 & 10.53 & 14.76 & V \\
Bruguiera gymnorrhiza & 3.33 & 0.23 & 5.26 & 8.82 & VII \\
Planted mangrove forest & & & & & \\
Avicennia marina & 14.19 & 9.48 & 10.00 & 33.67 & V \\
Ceriops tagal & 12.14 & 6.94 & 30.00 & 49.08 & IV \\
Lumnitzera racemosa & 1.41 & 0.09 & 5.00 & 6.50 & VI \\
Rhizophora apiculata & 25.45 & 30.49 & 20.00 & 75.95 & II \\
Rhizophora mucronata & 19.47 & 17.84 & 15.00 & 52.32 & III \\
Sonneratia alba & 27.33 & 35.15 & 20.00 & 82.49 & I \\
\hline & & & & & \\
\end{tabular}



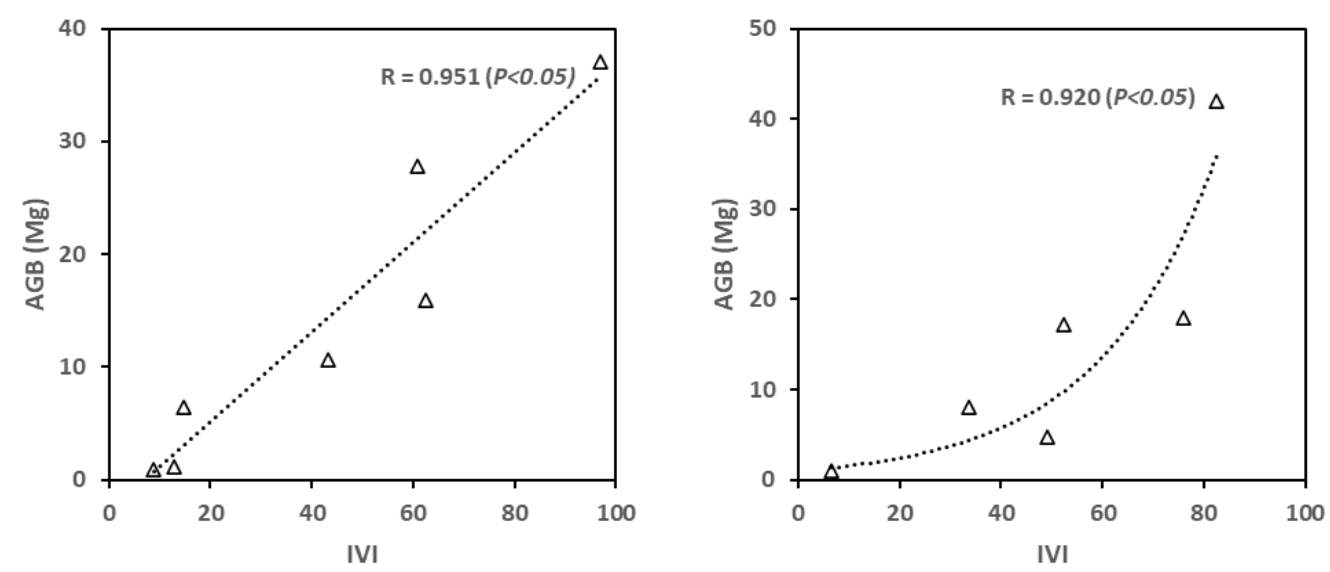

Figure 4. The relationship between important value index (IVI) and aboveground biomass (AGB) of each species in the natural mangroves (NF) and planted mangroves (PF)
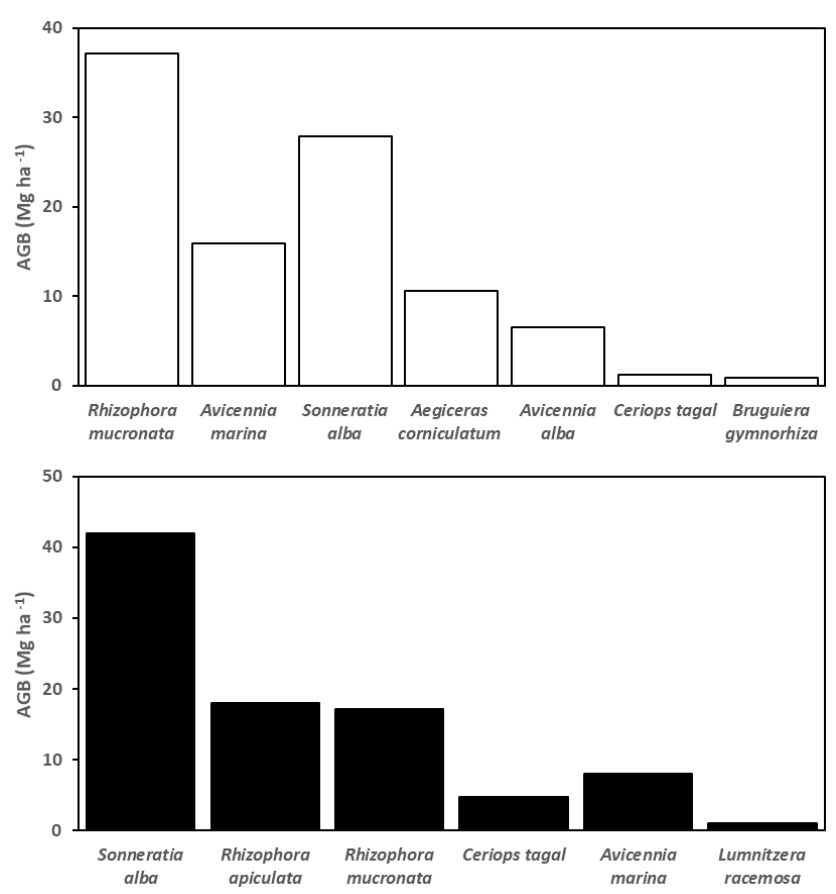

Figure 5. The aboveground biomass of each species in the natural mangroves (NF) and planted mangroves (PF) on the coast of Sikka, East Nusa Tenggara, Indonesia
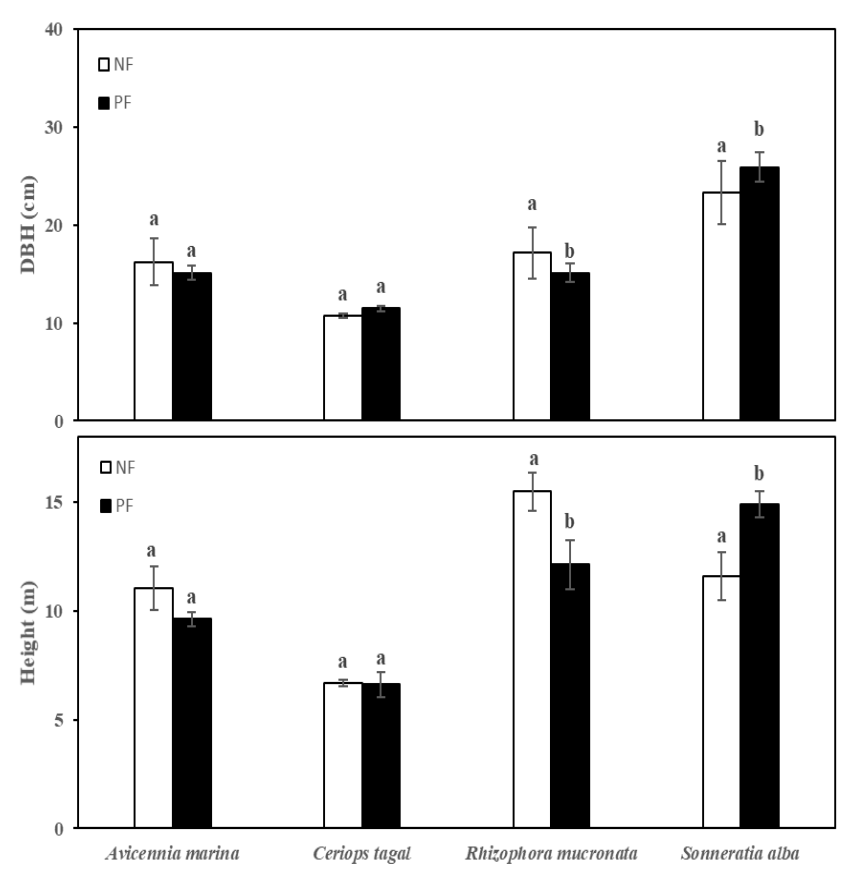

Figure 6. Comparison of the average diameter at breast height (DBH) and height from similar species found in the natural mangroves (NF) and planted mangroves (PF) in the coast of Sikka, East Nusa Tenggara, Indonesia

Table 3. Comparison growth, aboveground biomass, and species diversity between the natural mangroves (NF) and the planted mangroves (PF) in Sikka, East Nusa Tenggara, Indonesia

\begin{tabular}{llccc}
\hline \multirow{2}{*}{ Stand parameters } & \multirow{2}{*}{ Unit } & \multicolumn{2}{c}{ Type of mangrove } & \multirow{2}{*}{$\boldsymbol{P}$} \\
\cline { 3 - 4 } & & NF & $363 \pm 74$ & $0.773^{\mathrm{ns}}$ \\
Tree density & plant ha & & $0.003^{-1}$ \\
DBH & $\mathrm{cm}$ & $14.77 \pm 4.81$ & $14.64 \pm 3.68$ & $0.005^{* *}$ \\
Height & $\mathrm{m}$ & $11.34 \pm 4.15$ & $11.33 \pm 1.63$ & $0.727^{\mathrm{ns}}$ \\
Wood volume & $\mathrm{m}^{3} \mathrm{ha}^{-1}$ & $62.16 \pm 16.99$ & $62.57 \pm 24.51$ & $0.806^{\mathrm{ns}}$ \\
AGB & $\mathrm{Mgha}^{-1}$ & $66.74 \pm 16.79$ & $71.04 \pm 25.32$ & $0.772^{\mathrm{ns}}$ \\
Margallef index & - & $0.84 \pm 0.09$ & $0.74 \pm 0.40$ & $0.738^{\mathrm{ns}}$ \\
Shannon-Wiener Index & - & $1.07 \pm 0.18$ & $0.84 \pm 0.48$ & $0.563^{\text {ns }}$ \\
Pielou evenness index & - & $0.62 \pm 0.11$ & $0.52 \pm 0.30$ & \\
\hline
\end{tabular}

Note: Data are presented in mean \pm standard deviation. The mark of $* *$ indicates significantly different while ${ }^{\text {ns }}$ means not significantly different 
In conclusion, it was clearly exhibited that the stand structure, species diversity, and aboveground biomass between natural and planted mangroves in Sikka, East Nusa Tenggara was relatively equal. The findings of this study suggest that restoration efforts of degraded mangroves in Sikka have been effective. The restoration, which has been conducted for almost three decades, has not only brought back its vegetation cover but also the functional traits of the mangrove stand to mimic with natural mangroves in the area.

\section{ACKNOWLEDGEMENTS}

Authors deliver their gratitude to the Department of Research and Development of Trofsit Institute which provided financial support to conduct this study through the scheme of research collaboration about "Long-term Monitoring of Mangrove Reforestation in Flores Island" with a contract number 001/TRF/FLR/20. We also express our gratitude to the reviewer for their suggestion to improve the quality of the article.

\section{REFERENCES}

Angelini A, Portoghesi L, Corona, P. Chianucci, F. 2015. Structura attribus of stand overstory and light under the canopy. Ann Silvic Res 39: 23-31. DOI: 10.12899/ASR-993.

Bauhus J, McElhinny CM, Alcorn, P. 2002. Stand structure and tree growth in uneven-aged spotted gum (Corymbia maculata) forests: Some implications for management. Forestry 75: 451-456. DOI: 10.1093/forestry/75.4.451.

Dasgupta S, Islam MS, Huq M, Khan ZH, Hasib MR. 2019. Quantifying the protective capacity of mangroves from storm surges in coastal Bangladesh. PLoS One 14: 1-14. DOI: 10.1371/journal.pone.0214079.

Debrot AO, Veldhuizen A, van den Burg SWK, Klapwijk CJ, Islam MN, Alam MI, Ahsan MN, Ahmed MU, Hasan SR, Fadilah R, Noor YR Pribadi R, Rejeki S, Damastuti E, Koopmanschap E, Reinhard S, Scheltinga CT, Verburg C, Poelman M, 2020. Non-timber forest product livelihood-focused interventions in support of mangrove restoration: A call to action. Forests 11: 1-17. DOI: 10.3390/f11111224.

Dinilhuda A, Akbar AA, Jumiati, Herawati H. 2020. Potentials of mangrove ecosystem as storage of carbon for global warming mitigation. Biodiversitas 21: 5353-5362. DOI: 10.13057/biodiv/d211141.

Eddy S, Ridho MR, Iskandar I, Mulyana A. 2019. Species composition and structure of degraded mangrove vegetation in the Air Telang Protected Forest, South Sumatra, Indonesia. Biodiversitas 20: 2119 2127. DOI: $10.13057 /$ biodiv/d200804.

Gebeyehu G, Soromessa T, Bekele T, Teketay D. 2019. Species composition, stand structure, and regeneration status of tree species in dry Afromontane forests of Awi Zone, northwestern Ethiopia. Ecosyst Heal Sustain 5: 199-215. DOI: 10.1080/20964129.2019.1664938.

Guèze M, Luz AC, Paneque-Gálvez J, Macía MJ, Orta-Martínez M, Pino J, Reyes-García V. 2014. Are ecologically important tree species the most useful? a case study from indigenous people in the Bolivian Amazon. Econ Bot 68: 1-15. DOI: 10.1007/s12231-014-9257-8.

Hossain M, Shaikh MAA, Saha C, Abdullah SMR, Saha S, Siddique MRH. 2016. Above-ground biomass, nutrients and carbon in Aegiceras corniculatum of the Sundarbans. Open J For 6: 72-81. DOI 10.4236/ojf.2016.62007

Kangkuso A, Jamili J, Septiana A, Raya R, Sahidin I, Rianse U, Rahim S, Alfirman A, Sharma S, Nadaoka K. 2016. Allometric models and aboveground biomass of Lumnitzera racemosa Willd. forest in Rawa Aopa Watumohai National Park, Southeast Sulawesi, Indonesia. Forest Sci Technol 12: 43-50. DOI: 10.1080/21580103.2015.1034191.

Kasim F, Kadim MK, Nursinar S, Karim Z, Lamalango A. 2019 Comparison of true mangrove stands in Dudepo and Ponelo islands, north Gorontalo district, Indonesia. Biodiversitas J Biol Divers 20:
259-266. DOI: $10.13057 /$ biodiv/d200142

Koh H, Teh S, Kh'ng X, Raja Barizan R. 2018. Mangrove Forests : Protection Against. J Trop For Sci 30: 446-460.

Komiyama A, Havanond S, Srisawatt W, Mochida Y, Fujimoto K, Ohnishi T, Ishihara S, Miyagi T. 2000. Top/root biomass ratio of a secondary mangrove (Ceriops tagal (Perr.) C.B. Rob.) forest. For Ecol Manage 139: 127-134. DOI: 10.1016/S0378-1127(99)00339-4.

Krisnawati H. 2012. Monograph allometric models for estimating tree biomass at various ecosystems types in Indonesia. Ministry of Forestry, Bogor. DOI: 10.13140/RG.2.1.4139.2161.

Kusmana C, Sukristijiono S. 2016. Mangrove resource uses by local community in Indonesia. J Nat Resour Environ Manag 6: 217-224. DOI: $10.19081 /$ jpsl.2016.6.2.217.

Luo Z, Sun OJ, Xu H. 2010. A comparison of species composition and stand structure between planted and natural mangrove forests in Shenzhen Bay, Sout.h China. J Plant Ecol 3: 165-174. DOI: 10.1093/jpe/rtq004

Marois DE, Mitsch WJ. 2015. Coastal protection from tsunamis and cyclones provided by mangrove wetlands - A review. Intl J Biodivers Sci Ecosyst Serv Manag 11: 71-83. DOI: 10.1080/21513732.2014.997292

Njana MA. 2017. Indirect methods of tree biomass estimation and their uncertainties. South For 79: 41-49. DOI: 10.2989/20702620.2016.1233753

Pamoengkas P, Siregar IZ, Dwisutono AN, 2018. Stand structure and species composition of merbau in logged-over forest in Papua, $\begin{array}{llll}\text { Indonesia. } & \text { Biodiversitas } & 19: & 163-171 .\end{array}$ 10.13057/biodiv/d190123.

Pukkala T, Lähde E, Laiho O, 2010. Optimizing the structure and management of uneven-sized stands of Finland. Forestry 83: 129-142. DOI: 10.1093/forestry/cpp037.

Richards DR, Friess DA. 2016. Rates and drivers of mangrove deforestation in Southeast Asia, 2000-2012. Proc Natl Acad Sci USA 113: 344-349. DOI: 10.1073/pnas.1510272113.

Sadono R, Soeprijadi D, Susanti A, Matatula J, Pujiono E, Idris F, Wirabuana PYAP. 2020a. Local indigenous strategy to rehabilitate and conserve mangrove ecosystem in the southeastern Gulf of Kupang, East Nusa Tenggara, Indonesia. Biodiversitas 21: 12501257. DOI: $10.13057 /$ biodiv/d210353.

Sadono R, Soeprijadi D, Susanti A, Wirabuana PYAP, Matatula J. 2020 b. Short communication: Species composition and growth performance of mangrove forest at the coast of tanah merah, East Nusa Tenggara, Indonesia. Biodiversitas 21: 5800-5804. DOI: 10.13057/biodiv/d211242

Sghaier T, Cañellas I, Calama R, Sánchez-González M. 2016. Modelling diameter distribution of Tetraclinis articulata in Tunisia using normal and weibull distributions with parameters depending on stand variables. IForest 9: 702-709. DOI: 10.3832/ifor1688-008

Sihombing VS, Gunawan H, Sawitri R. 2017. Diversity and community structure of fish, plankton and benthos in Karangsong mangrove conservation areas, Indramayu, West Java, Indonesia. Biodiversitas 18: 601-608. DOI: 10.13057/biodiv/d180222.

Singh JK. 2020. Structural characteristics of mangrove forest in different coastal habitats of Gulf of Khambhat arid region of Gujarat, west coast of India. Heliyon 6: e04685. DOI: 10.1016/j.heliyon.2020.e04685.

Sinha A, Rämö J, Malo P, Kallio M, Tahvonen O. 2017. Optimal management of naturally regenerating uneven-aged forests. Eur $\mathrm{J}$ Oper Res 256: 886-900. DOI: 10.1016/j.ejor.2016.06.071.

Susilo H. Takahashi Y. Yabe M. 2017. The opportunity cost of labor for valuing mangrove restoration in Mahakam Delta, Indonesia. Sustainability 9: 1-13. DOI: 10.3390/su9122169.

Taillardat P. Friess DA, Lupascu M. 2018. Mangrove blue carbon strategies for climate change mitigation are most effective at the national scale. Biol Lett 14: 1-7. DOI: 10.1098/rsbl.2018.0251.

Turkis S, Elmas E. 2018. Tree species diversity and importance value of different forest communities in Yenice forests. Fresenius Environ Bull 27: 4440-4447.

Westphal C, Tremer N, Oheimb G, Hansen J, Gadow K, Härdtle W. 2006. Is the reverse $\mathrm{J}$-shaped diameter distribution universally applicable in European virgin beech forests?. For Ecol Manag 223: 75-83. DOI: 10.1016/j.foreco.2005.10.057

Yuliana E, Hewindati YT, Winata AD, Djatmiko WA, Rahadiati ATI. 2019. Diversity and characteristics of mangrove vegetation in Pulau Rimau Protection Forest, Banyuasin District, South Sumatra, Indonesia. Biodiversitas 20: 1215-1221. DOI: 10.13057/biodiv/d200438. 